J. Tumbahangfe, B.R. Subba and S.K. Jha.2014. Embryonic development of Bhakur Catla catla Hamilton 1822 (Cyprinidae). Our Nature 12 (1): 49-53. DOI: http://dx.doi.org/10.3126/on.v12i1.12257

\title{
Embryonic Development of Bhakur Catla Catla Hamilton 1822 (Cyprinidae)
}

\author{
J. Tumbahangfe* , B.R. Subba** and S.K. Jha \\ Department of Zoology, Post Graduate Campus, Tribhuvan University, Biratnagar, Nepal \\ E-mail:*jawan_subba@yahoo.com,**subbabr@gmail.com
}

Received: 19.09.2014; Accepted: 22.11.2014

\begin{abstract}
The present study was carried out to investigate the embryonic development of Bhakur, Catla catla. The incubation period of Bhakur was found to be $13 \mathrm{hrs}$ of post fertilization at $30 \pm 1^{\circ} \mathrm{C}$ of water temperature. The present work generated some important information on the early life history and developmental stages of Bhakur in Nepal. This study will help the fishery biologist in understanding the developmental biology of the fish, which might be of great use to take appropriate steps for the sustainable development of the culture, management, and production of indigenous breeds required for fish culture in Nepal climatic condition.
\end{abstract}

Key words: Embryonic development, Catla catla.

\section{Introduction}

Fishes are beautiful aquatic vertebrates which play an important role in aquatic ecosystem. Fishes are taken as an important aquatic resource which has economic values such as food, medicine, academic, aesthetic and also used for games. Unnaturally river damming, over fishing, electrical fishing, chemical poisoning, water pollution and introduction of exotic fishes species are becoming major problems which create threat to native fishes (Edds, 1986). According to Shrestha (2008) in the water resources of Nepal, 232 species of fishes are found. Among them 217 are indigenous and 15 exotic fishes (Shrestha, 2008).

Bhakur is eurythermal species that grows best at water temperature between $25-32^{\circ} \mathrm{C}$. Bhakur attains maturity in the second year performing a spawning migration during the Monsoon season towards the upper stretches of rivers. The spawning season is monsoon which lasts between May to August. Since, the riverine environment is required, natural breeding does not occur within ponds, even though the species attain maturity, thus hormonal induction is required. Under normal condition Bhakur grows to 1-1.2 kg in first year compared to 700-800g for Rohu and Mrigal respectively. So, this fish is very important in contest of commercial view to know the embryonic development.

\section{Materials and methods}

Following work was carried out in Regional Agricultural Research Station, Tarahara and Department of Zoology, Biratnagar.

\section{Brood selection}

The brood selection was done during the natural breeding season of Bhakur in May 2013 in the fish farm of Regional Agriculture Research Station, Tarahara. The selected broods were collected from brood ponds and were transferred to the tank of the hatchery. 


\section{Egg fertilization and incubation phase}

Two females and four males with the body weight $3-5 \mathrm{~kg}$ were used for induced breeding. Ovaprim hormone was used for induced breeding. $0.5 \mathrm{ml} / \mathrm{kg}$ and $0.25 \mathrm{ml} / \mathrm{kg}$ hormone doses were administered to females and males respectively. After 6 hrs of injection of hormone brood fish showed simple courtship behavior then eggs laying and fertilization of eggs took place simultaneously. Fertilized eggs were transferred into the circular incubation tank via inter connection system

\section{Image observation and analysis}

With the help of acute observation of courtship and spawning time, samples of fertilized eggs were collected very carefully from the spawning and incubation tanks using dropper in a Petri dish along with water. The developing stages of Catla catla were observed under the stereomicroscope (Nikon Eclipse E400) then photographed at every 10 minutes Interval up to hatching. For histological studies, the embryos were fixed in freshly prepared Bouin's fluid at room temperature 10-12 hours (two changes of freshly prepared Bouin's fluid were made at an interval of 5-6 hours) then samples were preserved in $70 \%$ alcohol. The chorion was manually removed then dehydrated in alcohol series; the naked embryos were embedded in paraffin and sectioned at $7 \mathrm{~m}$ with microtome. The section were doubled stained with hematoxylene and eosin, mounted in DPX and observed and photographed under an Olympus C35DX microscope.

\section{Measurement of fertilized egg}

Fertilized eggs were collected with the help of a dropper and preserved in freshly prepared Bouin's fluid and brought to the laboratory of Zoology Department, P. G. Campus Biratnagar, and kept for further work. The diameters of the eggs were measured with the help up of calibrated oculometer fixed in an eye piece of the microscope. 5 to10 specimens were measured and average diameter was calculated.

\section{Results}

\section{Morpho-embryological development}

Six hours after injecting ovaprim hormone, simple courtship behaviors of the fish were seen. During courtship, one female was being chased by two males. That event was shortly followed by eggs laying and milt releasing by females and males respectively.

The developmental stages were grouped into larger time blocks called periods i.e. Zygote period, Cleavage period, Blastula period, Gastrula period and Segmentation period (Table 1).

After fertilization chorion swells up (Figure 1A). The fully swollen egg was 4.5 $\mathrm{mm}$ in diameter. Fertilization activates the cytoplasmic movements and separates the non-yolky cytoplasms towards animal pole and yolk granule to vegetal pole. After first cleavage, the cell or blastomeres undergo division. The blastomers was divided int two distinct cells by vertical cleavage (Figure 1B), and become four cells (Figure 1C) within 50 minutes of fertilization. Then the cell in the egg was continuously developed to 32 cell, 64 cells and 128 cell, (Figure 1D-1F) respectively. After 4 hours 25 minutes, the onset of gastrulation was marked by $50 \%$ epiboly (Figure 1G). The distance between the animal and vegetal axis is covered by the blastoderm margin. 
Table 1.Period of early development of Bhakur embryos

\begin{tabular}{|l|l|l|}
\hline Period & Time & Description \\
\hline Zygote & 0 & Cytoplasm streams towards animal pole to form the blastodisc. \\
\hline Cleavage & $35 \mathrm{~min}$ & Blastomeres become arranged in more than one row. \\
\hline Blastula & $2 \mathrm{hrs}$ & $\begin{array}{l}\text { Cell division transits from synchrony to asynchrony at mid-blastula transition; } \\
\text { yolk syncytial layer forms and epiboly begin. }\end{array}$ \\
\hline Gastrula & $\begin{array}{l}4 \mathrm{hrs} \\
\text { min }\end{array}$ & $\begin{array}{l}\text { Involution, convergence and extension occur, forming the primary germ layers } \\
\text { and embryonic axis. }\end{array}$ \\
\hline Segmentation & $7 \mathrm{hrs}$ & Somites develop and organogenesis occurs, formation of tail. \\
\hline $\begin{array}{l}\text { Larva } \\
\text { (hatching) }\end{array}$ & $13 \mathrm{hrs}$ & Hatching occurs. \\
\hline
\end{tabular}

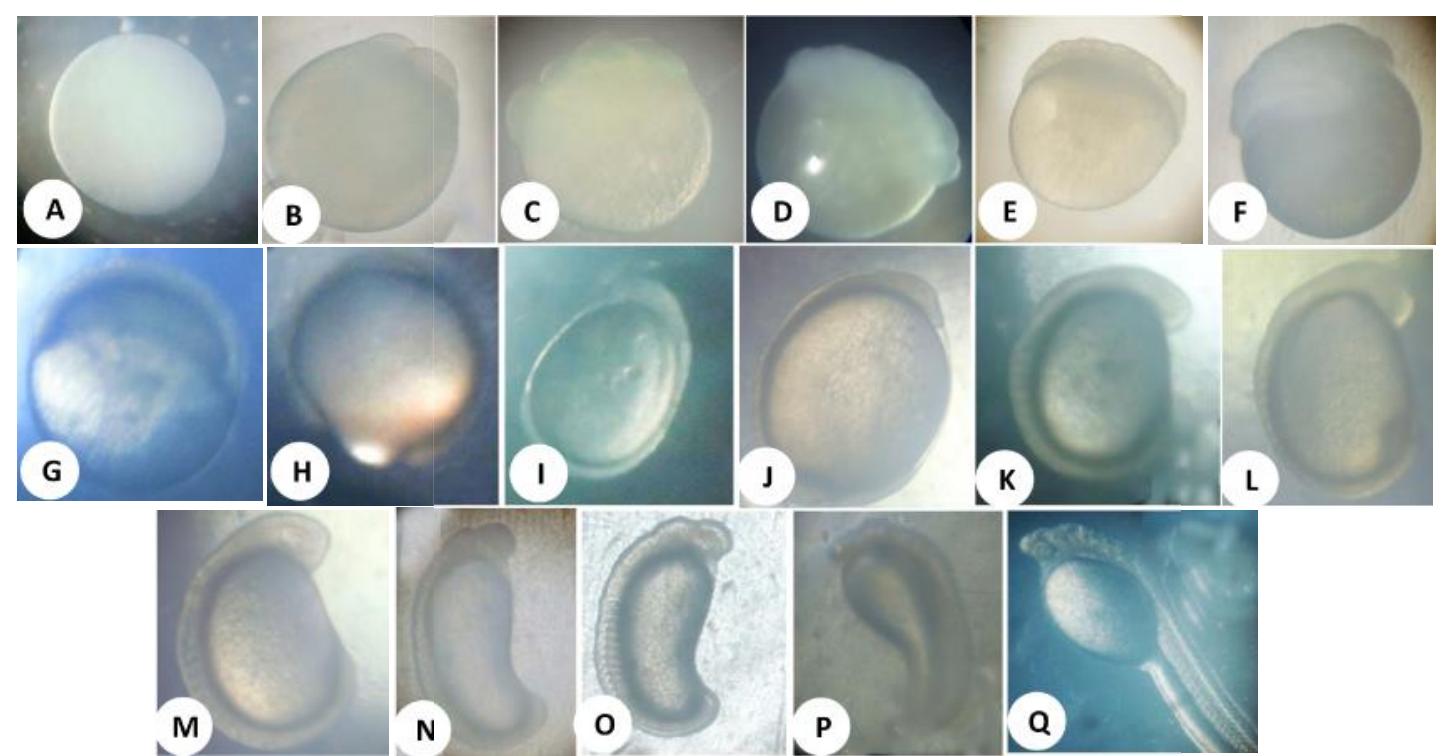

Figure 1. Embryoninc developmental stages of Catla catla, (A) Zygote, (B) 2-cell stage, (C) 4-cell stage, (D) 32-cell stage, (E) 64 cell stage, (F) 128 cell stage, (G) 50\% Epiboly, (H) 90\% Epiboly, (I) Tail bud stage, (J) 2 somites, (K) 6 somites (L) 8 somites, (M) 12 somites, (N) 18 somites, (O) 20 somites, (P) 30 somites, and (Q) Hatched larva .

The thickened annulus at the blstoderm margin forms the germ ring. The epiboly continues and reached to $90 \%$ epiboly at 5 hours 40 minutes after fertilizatio, fig. $-1 \mathrm{H}$. As the blastoderm almost covers the yolk, the yolk plug can be seen protruding from the vegetal pole. The blastoderm fully covers the yolk plug and epiboly completes during tailbud stage (Figure I). After epiboly segmentation starts and formation of somites takes place i.e. 2-somites stage, 6-somites stage, 12-somites stage, 18somites stage, 20-somites stage and 30somites stage, (Figure 1J-1P), respectively. Finally, the embryo hatched at 13 hours post fertilization. The larva was entirely transparent and pigmentations were not found (Figure 1Q).

\section{Histo-embryological development}

Histological section of 4-celled stage clearly shows the division of zyote in to four cells 
(Figure 2A). Histological section of gastrulation reveals a distinct thickening of the rim of the blastoderm (Figure 2B). In the section of yolk sac fry, notochord formation, development of somites and neural tube are seen (Figure 2C-2D).

\section{Discussion}

The embryonic period was counted from the time when the eggs were fertilized by sperm and ended until the embryo has hatched out. Bhakur, breeding is done successfully in Nepal, however, there is no record of embryonic development study of this fish in Nepal. This present attempt claims to be the first work in the contest of Nepal in embryonic development of Bhakur. This study defines a detailed table of normal development of the Bhakur ranging from fertilization to post hatching. The eggs produced by female Bhakur are spherical, non-floating and non-adhesive. The diameter of fertilized swollen eggs of Bhakur was reported to be 5.3-6.5 mm (Mookerjee, 1945) but in the present study; diameter of the fully swollen egg was 4.5 $\mathrm{mm}$. Eight cell stage of Bhakur embryo was found in $1 \mathrm{hr} .29 \mathrm{~min}$ after fertilization (Mookerjee, 1945) but in the present study 8- cell stage was found in $1 \mathrm{hr} 5 \mathrm{~min}$ i.e. 24 minutes faster than that of Mookerjee. Mookerjee, (1945) has described 16- cell stage in $1 \mathrm{hr} 45 \mathrm{~min}$ but the stage was observed after $1 \mathrm{hr} 20 \mathrm{~min}$ after fertilization. 32-cell stage was observed in $2 \mathrm{hr} 39 \mathrm{~min}$ (Mookerjee, 1945) but in Bhakur it was observed after $1 \mathrm{hr} 35 \mathrm{~min}$. The period of incubation of Catla catla was about 14-24 $\mathrm{hr}$ in $23-33^{\circ} \mathrm{C}$ temperature (Kunal, 2011) but the same observation was made after 13 hrs in $29-31^{0} \mathrm{C}$. These differences might have occurred due to the differences in size of brood stocks and temperature of water at the time of hatching. The development of Bhakur differs in several respects from that of rosy barb and zebra fish. The hatching of Bhakur was recordedto be $13 \mathrm{hrs}$ post fertilization when reared at $30{ }^{\circ} \mathrm{C}$ that was faster than those of the rosy barb (Bhattacharya, 2006) and the Zebra fish (Kimmel et al., 1995). Pigmentaion was not visible in any region of the Bhakur embryos until hatching, while pigmentation had already occurred in the zebra fish embryos prior to hatching (Kelsh et.al., 1996). Trunk and tail contraction occurs initially in the 16 -somites and 18-somites stage embryos of Catla catla respectively. The muscular contraction manifests the establishment of neuromuscular interaction appears to be established sequentially in the trunk and tail with anterior neuromuscular interaction developed earlier and posterior ones slightly later (Bhattacharya, 2006). In P. jullieni, the second cleavage (4-cell stage) occurred at 1 hr $40 \mathrm{~min}$, but in Catla catla, second cleavage occurred in $50 \mathrm{~min}$ after fertilization which was much faster. The hatching of $P$. jullieni was observed to be at $24 \mathrm{hr}$ after fertilization (Zakaria, 2013) but in Catla catla, I observed to be at $13 \mathrm{hr}$ after fertilization. This situation happened due to the differences in species and water temperature during hatching.

\section{Acknowledgements}

The authors are grateful to the Department of Zoology, Post Graduate Campus, Biratnagar for providing lab facilities. We would like to acknowledge University Grants Commission Nepal for financial support to carry out this project. The cooperation of Regional Agricultural 


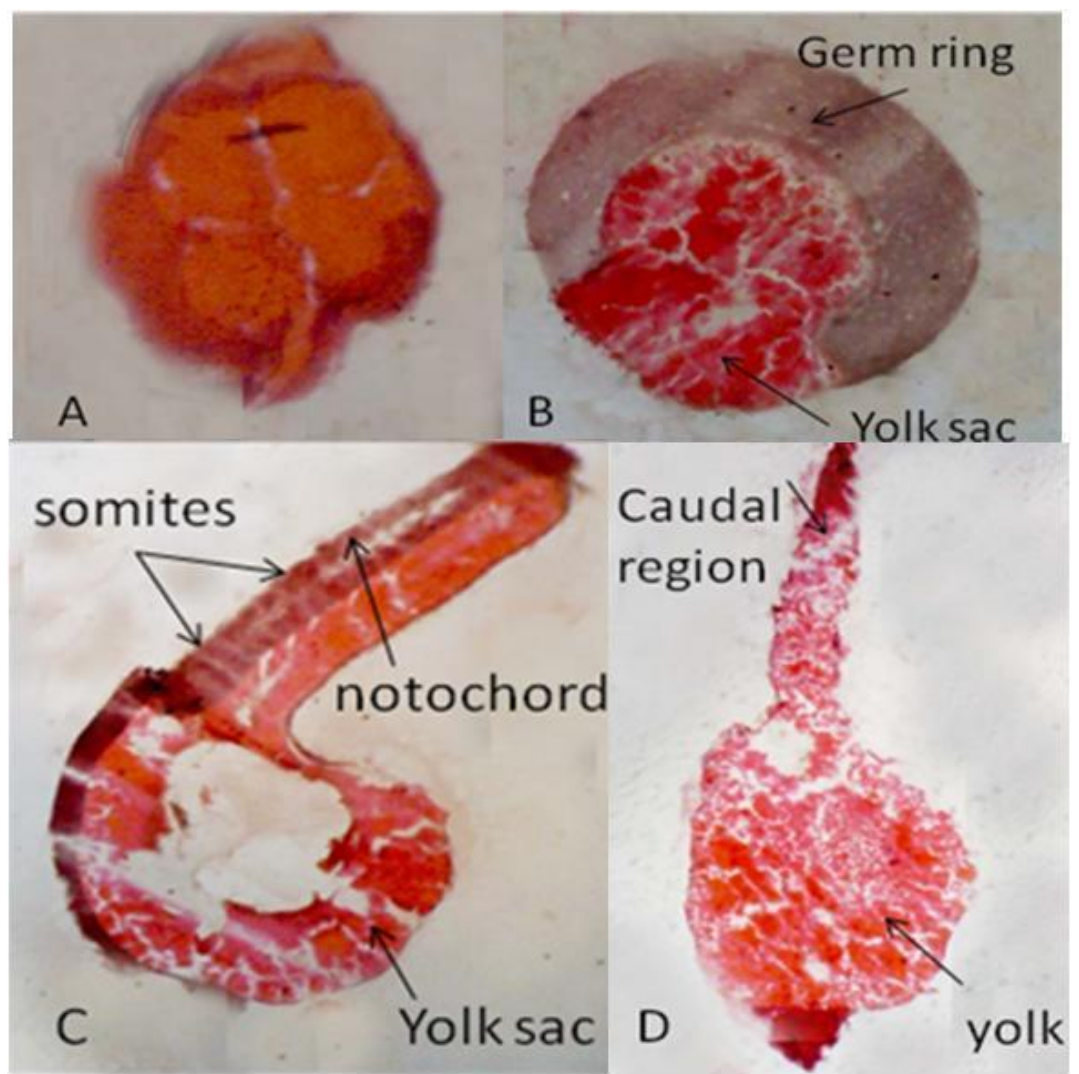

Figure 2. Micrograph of (A) Cleavage period showing four cells stage of embryo (B) Gastrulation showing distinct thickening of the rim of the blastoderm, (C and D) yolk sac fry, Notochord formation in posterior region of the embryo.

Research Station, Tarahara is highly appreciated and cordially acknowledged for providing facilities and technical support to carry out the present work.

\section{References}

Bhattacharya, H. 2006. Promotion of a model fish rosy barb (Puntius conchonius) embryogenesis, effect of salinity on early development and histopathological toxicity to $\mathrm{CCl} 4$. Ocean University of China, Qingadao (Ph.D. Thesis).

Edds, D.R. 1986. Fishes of Kali Gandaki/Narayani Rivers, Nepal. J. Nat. Hist. Mus. 10(14): 13-22.

Hamilton, F. 1822. An account of the fishes found in $t$ he river Ganga and its branches. Edinburg. 405p.

Kelsh, R.N., M. Brand, Y.J. Jiang, C.P. Heisenberg, S. Lin and P. Haffter 1996. Zebrafish pigme- ntation mutations and the processes of neural crest development. Development 123: 369-389.

Kimmel, C.B., W.W. Ballard, S.R. Kimmel, B. Ullmann and T.F. Schilling 1995. Stages of embryonic development of the zebrafish. Developmental Dynamics 203: 253-310.

Kunal, K. 2011. Egg and embryonic development in Indian Major Carps (IMC). Kishor Kunal Fisheries College and research institute.

Mookerjee, H. K. 1945. Life histories of some major carps of Bengal. Sc. and Cult. 10(9): 400-402.

Shrestha, T.K. 2008. Ichthyology of Nepal. Himalayan Ecosphere, Kathmandu, Nepal.

Zakaria, M.H., S.M.N. Amin, A.M. Rahman, H.M. Mahmud, A. Christianus, S.S. Siraj et al. 2013. Embryonic and larval development of endangered temoleh, Probarbus jullieni (Sauvage). Asian Journal of Animal and Veterinary Advance 8 : 362-268. 